\title{
JoECCE
}

Journal of Early Childhood and Character Education Vol 1, No : 2, 2021

\section{Stimulasi Bermain Peran Bagi Keterlambatan Bicara Pada Anak Usia 3 Tahun}

\author{
Asrul Faruq \\ Sekolah Tinggi IlmuTarbiyah Pemalang \\ asrulfaruq@stitpemalang.ac.id
}

Dhiarti Tejaningrum

Sekolah Tinggi Pendidikan Islam Bina InsanMulia Yogyakarta

artieteja@gmail.com

\section{Abstrak}

Language development is an important part for early childhood. Language is a tool communication children to express themselves. The delay in the child's speaking ability will hinder aspects of the level of achievement of the child's development. Child development achievement level is an indicator of growth and development that is expected to be achieved by children in a certain time span.

This study aims to analyze how to overcome speech delays in children aged 3 years through the stimulation of role playing activities carried out at Safa Preschool Yogyakarta. The method in this study is a qualitative research with conduct interviews and observations. The results show that role play stimulation can reduce speech delay in children aged 3 years and improve speech and language skills in children optimally.

Kata Kunci: Early Childhood, Language Development, Language Development Disorders. 


\section{ABSTRAK}

Perkembangan bahasa merupakan bagian penting bagi anak usia dini. Bahasa adalah alat komunikasi anak untuk mengekspresikan diri. Keterlambatan kemampuan berbicara anak akan menghambat aspek tingkat pencapaian perkembangan anak. Tingkat pencapaian perkembangan anak merupakan indikator pertumbuhan dan perkembangan yang diharapkan dapat dicapai anak pada rentang waktu tertentu.

Penelitian ini bertujuan untuk menganalisa cara mengatasi keterlambatan bicara pada anak usia 3 tahun melalui stimulasi kegiatan main peran yang dilakukan di Safa Preschool Yogyakarta. Metode dalam penelitian ini adalah penelitian kualitatif dengan melakukan wawancara dan observasi. Hasil menunjukkan bahwa stimulasi bermain peran mampu mengurangi keterlambatan bicara pada anak usia 3 tahun serta meningkatkan kemampuan bicara dan bahasa pada anak secara optimal.

Kata kunci : Anak Usia Dini, Perkembangan Bahasa, Gangguan Perkembangan Bahasa. 


\section{PENDAHULUAN}

Pendidikan dapat diartikan sebagai bimbingan atau pertolongan yang diberikan kepada anak oleh orang dewasa untuk mencapai perkembangan kedewasaannya dengan tujuan agar anak terampil melaksanakan tugas hidupnya dan tidak tergantung dengan orang lain. Pendidikan juga merupakan sebuah proses sadar untuk mengembangkan potensi individu sehingga memiliki kecerdasan pikir, berwatak mulia, mengendalikan emosi dan mempunyai keterampilan untuk siap hidup di lingkungan masyarakat. Oleh sebab itu, pendidikan sangat dibutuhkan oleh anak mulai dari kandungan ibu hingga dewasa. Sesuai dengan tujuan pendidikan anak usia dini di atas, pendidikan anak usia dini (PAUD) secara umum memiliki tujuan untuk membentuk karakter anak Indonesia yang berkualitas, yaitu anak yang tumbuh dan berkembang sesuai dengan tahapan perkembangannya sehingga memiliki kesiapan yang optimal untuk memasuki pendidikan dasar, melanjutkan kehidupan ke fase selanjutnya serta membantu menyiapkan anak mencapai kesiapan dan kesuksesan belajar (akademik) di sekolah.

Pendidikan anak usia dini stimulasikan untuk mengembangkan pengetahuan, keterampilan dan pribadi individu yang melandasi pendidikan dasar, mengembangkan diri secara utuh sesuai dengan asas pendidikan sedinimungkin dan seumur hidup. PAUD merupakan pondasi awal dalam meningkatkan kemampuan anak untuk menyelesaikan pendidikan yang lebih tinggi, menurunkan angka mengulang dan putus sekolah. Aspek perkembangan anak menjadi tujuan penting dan utama dalam pendidikan anak usia dini. Beberapa aspek tersebut dapat dikembangkan melalui aktivitas pembelajaran. Aspek kemampuan anak yang dikembangkan meliputi bahasa, kognitif, fisik-motorik, seni, dan sosial emosional. Usia dini merupakan usia emas (golden age), dimana aspek kemampuan anak berkembang sangat pesat.

Kecerdasan anak memang berbeda-beda, kecerdasan secara umum digolongkan dalam tiga (3) aspek yaitu kemampuan bentuk pikir, kemampuan belajar dan kemampuan menyesuaikan diri. Ketiga aspek tersebut dapat berkembang dengan baik apabila kemampuan berbahasa anak juga baik. Kemampuan bicara dan bahasa sangat penting dalam kehidupan. Sebagian besar orang mempunyai kesulitan untuk berbicara dalam keadaan tegang atau dalam situasi sosial 


\section{Asrul Faruq, Dhiarti Tejaningrum 156}

tertentu namun hal itu dapat diatasi jika orang tersebut dengan terus berlatih untuk menghadapi situasi tersebut dan bukan merupakan gangguan yang berarti.

\section{KAJIAN TEORI}

\section{Karakteristik Anak Usia Dini}

Tahap pertumbuhan dan perkembangan anak usia dini berada pada fase paling pesat dari segi fisik dan mental. Usia dini merupakan usia emas (golden age). Anak berpotensi untuk mempelajari banyak hal dengan cepat. Pada fase ini, anak juga mampu menyerap berbagai informasi dengan sangat mudah. Perkembangan (development) merupakan bertambahnya keterampilan (skill) struktur tubuh yang sangat komplek dalam pola yang teratur dan dapat diramalkan sebagai proses pematangan(Soetjiningsih, 1995). Perkembangan juga merupakan bertambahnya kemampuan dalam struktur, kapasitas, dan fungsi sebagai proses kematangan (Hamalik, 2004). Perkembangan merupakan hasil dari proses kematangan dan belajar. Ciri anak pra-sekolah (3-6 tahun) meliputi aspek sosial-emosional, fisik dan kognitif atau intelegensia, moral dan bahasa. Seluruh aspek perkembangan anak saling berhubungan.

\section{a. Perkembangan fisik motorik}

Perkembangan fisik dan motorik anak usia dini meliputi kemampuan fisik, motorik halus dan kasar. Pertumbuhan fisik anak menggambarkan struktur tubuh pada anak, sedangkan kemampuan gerak atau motorik digambarkan dengan koordinasi berbagai otot tubuh untuk bergerak. Otot kecil berfungsi sebagai kontrol terhadap jari dan tangan. Fisik anak laki-laki lebih besar dari anak perempuan dan membutuhkan istirahat yang cukup setelah melakukan berbagai kegiatan dan tubuh mereka lentur.(Patmodewo, 2003). Perkembangan gerak anak meliputi gerakan yang lebih terkendali dan terorganisasi seperti menegakkan tubuh dalam posisi berdiri, tangan dapat terjuntai secara santai, dan mampu melangkahkan kaki dengan menggerakkan tungkai dan kaki. Perkembangan motorik halus anak usia dini ditandai dengan koordinasi motorik halus anak telah meningkat dan menjadi lebih cepat. 


\section{b. Perkembangan kognitif}

Sesuai dengan tahap perkembangan kognitif dari Piaget, anak usia dini berada pada tahap sensorimotor (usia 0-2 tahun) dan pra operasional (2-7 tahun). Tahap sensorimotor berarti anak membentuk pemahaman dan pengetahuan mengenai dinamika dunia dengan menggabungkan pengalaman sensori anak yang ebrasal dari indera dengan tindakan gerak fisik. Sedangkan tahap pra-operasional, yaitu tahapan anak belum menguasai kemampuan mental dan logika. Periode ini ditandai dengan kemampuan anak menggunakan suatu benda yang berkembang sebagai simbol atau ide maupun pikiran anak. Perkembangan kognitif anak pada masa pra-sekolah meliputi, kemampuan berpikir dengan menggunakan simbol, meskipun masih dibatasi oleh persepsi atau cara berpikir anak yang kaku namun anak mulai mengerti dasar-dasar pengelompokan suatu konsep atas dasar satu dimensi (Masito, 2005).

\section{c. Perkembangan bahasa}

Perkembangan bahasa anak usia dini ditandai dengan peningkatana keterampilan berbicara anak (Masito, 2005). Anak sangat senang dan aktif berbicara dan dapat menggunakan bahasa dengan metode bertanya, berdialog serta bernyanyi. Perkembangan bahasa anak juga ditandai dengan anak yang telah memiliki minat baca dan penguasaan kosa kata mereka sangat pesat. Setelah usia enam tahun, kosakata anak berkembang mencapai sekitar 3000 kata. Perkembangan kosakata anak mencapai lebih dari 15000 kata dan mereka selalu memperoleh kata baru dengan kecepatan 10 kata perhari. Perkembangan bahasa mengikuti urutan yang diramalkan secara umum meskipun memiliki variasi untuk mengembangkannya. Anak akan cenderung belajar nama benda sebelum kata-kata yang lain. Kemampuan bahasa verbal anak berkaitan dengan kemampuan kognitif mereka. Bahasa dan pola pikir merupakan dua aspek yang berbeda. Bahasa merupakan ungkapan dari pikiran yang telah disusun lengkap menjadi sebuah gabungan kesatuan yang memiliki makna. 


\section{d. Perkembangan sosial emosional}

Perkembangan emosional anak ditandai oleh anak yang mampu melakukan partisipasi aktif dan inisiatif melakukan kegiatan fisik. Anak berubah lebih asertif dan mampu berinisiatif kreatif. Perkembangan sosial anak ditandai dengan penyesuaian diri dengan lingkungan sekitar. Muncul kesadaran dari anak terhadap konsep diri yang berkenaan dengan kesetaraan gender. Perkembangan emosional dan psikologis anak pada usia ini cenderung egosentris dan iri hati, mereka mampu mengekspresikan emosi dengan terbuka dan bebas(Patmodewo, 2003). Aspek perkembangan di atas merupakan karakteristik dan tingkat perkembangan anak yang merupakan pencapaian aktualisasi potensi anak dari segala aspek perkembangan yang diharapkan berkembang dapat dicapai oleh anak secara optimal sesuai tahap perkembangannya dan bukan merupakan tingkat pencapaian kecakapan akademik.

\section{Perkembangan Bahasa Anak Usia Dini}

Pada tahap anak usia dini, segala aspek perkembangan mereka berkembang dengan pesat, karena merupakan usia emas dimana anak-anak dapat dengan baik memproses stimulasi yang diberikan. Seluruh aspek perkembangan anak berkembang secara kontinyu dan berkelanjutan termasuk perkembangan bahasa anak. Kemampuan perbendaharaan kosa kata mereka meningkat dan anak mulai menggunakan kalimat yang kompleks. Anak menggunakan penguasaan kosa kata dan kalimat untuk berkomunikasi. Perkembangan bahasa anak juga dapat dilihat dari cara anak berfikir atau menyelesaikan masalah.

Proses perkembangan disebut juga dengan perubahan dan kestabilan. Perubahan akan perkembangan dibedakan menjadi dua, yaitu perubahan kuantitati dan kualitatif (Papalia, Diane E; Old, Sally Wendkos \& Feldman, 2008). Perubahan kuantitif adalah perubahan angka maupun jumlah, seperti tinggi, berat, dan jumlah kosa kata. Sedangkan perubahan kualitatif merupakan perubahan pada jenis, struktur dan organisasi seperti perubahan cara berkomunikasi non-verbal menuju verbal. Proses perkembangan merupakan perubahan yang 
berlangsung terus-menerus dan bersifat tetap dari fungsi jasmani dan rohani yang dimiliki individu menuju kematangan melalui tahap pertumbuhan, pematangan dan belajar (Mar'at, n.d.). Perkembangan merupakan serangkaian perubahan yang terjadi secara progresif sebagai akibat dari proses kematangan dan pengalaman (Hurlock, 1999). Sis Heyster mengemukakan tiga (3) fungsi bahasa, yaitu: (1) bahasa sebagai media pernyataan isi jiwa; (2) bahasa sebagai peresapan (mempengaruhi orang lain); (3) bahasa sebagai alat menyampaikan pendapat(Ahmadi, Abu \& Sholeh, 2005).

Bahasa merupakan bentuk komunikasi lisan, tulisan maupun isyarat yang berdasarkan pada suatu sistem dari simbol(Santrock, 2007). Bahasa berperan sangat penting bagi manusia. Bahasa dapat mengungkapkan apa yang sedang dipikirkan, dirasakan dan dapat mendeskripsikan kejadiankejadian yang terjadi. Bahasa manusia memiliki karakteristik umum berupa generativitas tak terbatas dan aturan organisasi disekitar. Generativitas tak terbatas merupakan kemampuan memproduksi kata dan kalimat bermakna dalam jumlah tak terhingga dengan menggunakan kata-kata dan aturan-aturan yang terbatas. Bahasa memiliki sifat tertata dan aturan mendeskripsikan cara bahasa tersebut mampu memiliki makna(Santrock, 2007).

Bahasa adalah sejumlah unsur yang diatur, sebuah sistem tanda (hal atau benda yang menimbulkan reaksi), berupa bunyi, sebuah alat unuk berkomunikasi, bersifat produktif karena dapat dipakai secara tidak terbatas dan memiliki sifat unik karena memiliki sistem yang khas dan bersifat universal(Kushartanti, 2005). Perkembangan bahasa adalah proses perubahan secara kontinyu dan bersifat tetap sebagai akibat dari proses kematangan dan pengalaman dalam bentuk komunikasi lisan, tulisan maupun simbol yang dapat menjadi sarana penyampaian informasi maupun hubungan sosial dengan orang lain.

Akhadiah, dkk menyebutkan bahwa anak dapat tumbuh maksimal dari organisme biologis menjadi pribadi yang mampu berpikir, bersikap, merasakan, berbuat serta memandang dunia dan kehidupan seperti masyarakat di sekitarnya dalam kelompok (Suhartono, 2005). Bahasa merupakan serangkaian 
bunyi yang melambangkan pikiran, perasaan, serta sikap. Bahasa anak merupakan bahasa yang digunakan untuk menyampaikan keinginan, pikiran, harapan, permintaan oleh anak. Perkembangan bahasa anak merupakan komunikasi dan pemahaman melalui kata, perkataan dan tulisan.

Keinginan anak untuk belajar berbicara sangat kuat. Hal ini disebabkan karena berbicara merupakan media pokok bersosialisasi dan sarana mengembangkan kemandirian. Dnak akan lebih mudah berkomunikasi dengan teman sebaya, orang dewasa dan lingkungan dengan berbicara dan anak juga akan diterima dalam kelompok. Anak yang mengalami kesulitan berbicara akan mengalami hambatan dalam perkembangan kognitif dan sosial emosional. Kemampuan berbicara anak akan membantu mereka untuk mengungkapkan keinginannya dan membantu meningkatkan rasa percaya diri mereka. Tugas pokok anak dalam berkomunikasi ada tiga, yang pertama anak harus meningkatkan kemampuan untuk mengerti apa yang dikatakan orang lain; kedua anak harus meningkatkan kemampuan berbicara, sehingga keinginan anak dapat dimengerti oleh orang lain (Hurlock, 1999).

Schaerlaekens membedakan perkembangan bahasa pada anak usia 3 tahun (Mar'at, n.d.), yaitu: (1) periode pralingual (kalimat-satu-kata); (2) periode lingual awal (kalimatdua-kata); (3) periode differensiasi (menggunakan kalimat tigakata dengan bertambahnya differensiasi pada kelompok kata dan kecapan verbal). Perkembangan bicara anak berkembang menjadi bahasa sosial. Bahasa sosial digunakan anak untuk berhubungan, bertukar pikiran dan mempengaruhi orang lain. Bentuk komunikasi bahasa yang digunakan anak berupa keluhan, aduan, pertanyaan, kritikan, dsb. Ketika bahasa yang bersifat egosentris berubah menjadi bahasa sosial, maka terjadi penyatuan antara bahasa dan pikiran yang kemudian akan berpengaruh pada pembentukan kognitif dan mental anak.

Bahasa berkaitan erat dengan kemampuan kognitif. Kemampuan bahasa anak menjadi sarana pertumbuhan anak untuk membantu mengekspresikan pandangan anak tentang dunia. Anak prasekolah membuat perkembangan yang sangat pesat pada tata bahasa, kosa kata, dan sintaksis, kemampuan bicara pragmatis dan sosial. Anak usia 3 tahun dapat 
menggunakan 900 hingga 1000 kata dan mengucapkan lebih dari 12.000 kata setiap harinya. Owens (Papalia, Diane E; Old, Sally Wendkos \& Feldman, 2008) berpendapat bahwa kosa kata anak yang reseptif dan pasif (kata yang dapat dimengerti olehnya) akan bertambah empat kali lipat hingga 80.000 kata pada saat mereka memasuki sekolah menengah umum jika mereka masuk ke sekolah formal.

Anak dapat mengembangkan kosa kata dengan cepat menggunakan pemetaan kilat (fast mapping), yaitu tahapan anak menyerap makna dari kata baru setelah mereka mendengar kata tersebut beberapa kali dalam percakapan (Papalia, Diane E; Old, Sally Wendkos \& Feldman, 2008). Anak dapat membuat hipotesis tentang makna dari kata yang mereka dengar dan menyiapkan kata tersebut dalam ingatannya.

Berbicara tahap perkembangan bahasa tidak lepas dengan sistem aturan bahasa. Sistem aturan bahasa meliputi lima sistem (Santrock, 2007), yaitu fonologo, morfologi, semantik, sintaksis, dan pragmatik. Fonologi merupakan sistem suara pada sebuah bahasa yang dipakai dan mengkombinasikan suara dan bahasa tersebut. Fonologi merupakan tahap dimana anak memperoleh fonem yang merupakan unit terkecil dalam sebuah bahasa. Morfologi merupakan sistem dari komunikasi bermakna yang terlibat dalam pembentukan kata. Unit terkecil tersebut memiliki makna yang disebut dengan morfem atau kata. Sintaksis yaitu cara pengkombinasian kata-kata sehingga membentuk frase dan kalimat bermakna atau dapat diterima. Semantik merupakan makna kata dalam kalimat atau memahami kosakata. Sedangkan pragmatik adalah pemakaian bahasa sesuai dengan konteks, bisasanya digunakan dalam proses percakapan.

\section{Perkembangan Berbicara Anak Usia Dini}

Bicara merupakan cara untuk menyampaikan pikiran, informasi, perasaan dan gagasan kepada orang lain secara lisan. Para pakar komunikasi, menyebutkan bahwa bicara merupakan kemampuan mengucapkan bunyi artikulasi atau kata untuk menyatakan, mengekspresikan serta menyampaikan pikiran, gagasan dan perasaan(Tarigan, 1985). Berbicara juga merupakan suatu proses berkomunikasi, karena terjadi pesan dari suatu sumber ke sumber yang lain (Zamzami, n.d.). Berbicara merupakan 
bentuk dari perilaku manusia yang memanfaatkan faktor fisik, psikologi, neurologi, semantik dan linguistik (Suhartono, 2005).

Pada saat anak berbicara, mereka memanfaatkan fisiknya seperti mulut, pita suara, bentuk muka untuk menghasilkan bunyi bahasa. Pengendalian emosi berpengaruh terhadap kelancaran berbicara, kualitas suara dan keruntutan bahan pembicaraan. Sedangkan bunyi yang dihasilkan oleh alat ucap dan kata harus disusun menurut aturan tertentu agar bermakna, sehingga dapat dipahami oleh lawan bicara.

Berbicara merupakan suatu penyampaian maksud tertentu oleh manusia dengan mengucapkan bunyi bahasa supaya bunyi tersebut dapat dipahami oleh orang yang mendengar(Suhartono, 2005). Perkembangan bicara anak usia dini adalah proses yang tetap dan berkesinambungan untuk mengembangkan kemampuan bunyi bahasa yang dipengaruhi oleh faktor fisik, psikologi, neurologi, semanti dan linguistik sehingga orang lain dapat memahami perasaan, pikiran dan informasi yang diberikan oleh anak.

Setiap anak yang baru lahir, memiliki potensi bahasa yang baik. Hal ini ditunjukan ketika bayi memiliki bunyi tangisan yang bebeda-beda. Pemahaman kata dikomunikasikan melalui aktivitas mendengar dan bicara. Perkembangan berbicara berhubungan dengan morfologi, fonologi, sintaksis dan semantik. Anak mendengarkan bunyi-bunyi bahasa yang ada disekitarnya kemudian digunakan anak sebagai awal kegiatan bicara yaitu dengan menirukan ujaran yang telah didengar anak. Semakin usia anak bertambah, anak mulai mengucapkan kata-kata dari segi urutan kata dan jumlah kata berbeda dari apa yang telah anak dengar. Menurut Steinberg dan Gleason, perkembangan bahasa anak dibagi menjadi tiga yaitu perkembangan prasekolah, kombinatori dan masa sekolah (Suhartono, 2005):

\section{a. Perkembangan Bicara Anak Pra-Sekolah}

Perkembangan bicara anak sebelum memasuki sekolah diawali dengan komunikasi anak yang mayoritas berbentuk bunyi dari tangisan anak. Tahap perkembangan awal anak yaitu tahap telegrafis, penamaan dan transformasion (Suhartono, 2005). Pada tahap pertama, anak mulai mengutarakan dan mengurutkan bunyi kata tertentu namun belum mampu memaknainya. Anak mampu mengucapkan kata tersebut tapi 
belum mampu mengenal kata yang diucapkan. Pada tahap ini terjadi suatu proses peniruan bunyi yang pernah didengar oleh anak. Anak menirukan bunyi disekeliling anak, kemudian secara perlahan-lahan anak mengasosiasikan bunyi tersebut dengan peristiwa, situasi, benda, kegiatan, dsb. yang pernah dikenal anak melalui lingkungan. Pada tahap ini, anak menggunakan kalimat yang terdiri dari satu kata atau frase. Pada tahap telegrafis, anak mulai menyampaikan gagasan dan pesan dalam bentuk urutan bunyi yang berupa dua atau tiga kata untuk menggantikan kalimat yang berisi maksud dan makna tertentu. Ungkapan yang terdiri tiga kata memiliki struktur yang sangat singkat dan padat seperti telegram. Tahap transformasional merupakan mengeluarkan gagasan yang lebih lengkap dari tahapan telegrafis. Pengetahuan dan penguasaan kata-kata tertentu yang dimiliki anak dimanfaatkan untuk mengucapkan kalimat yang lebih rumit. Anak sudah berani mentransformasikan idenya kepada orang lain dalam bentuk kalimat yang beragam seperti menyuruh, menyanggah, bertanya dan menginformasikan sesuatu.

\section{b. Perkembangan Bicara Kombinatori}

Pada tahapn ini, anak sudah mampu menggunakan bahasa dalam bentuk interogatif, negatif dan menggabungkan preposisi menjadi sebuah kalimat tunggal. Kalimat yang diungkapkan anak mengarah pada kalimat pendek dan sederhana. Perkembangan bicara kombinatori dilalui anak sekitar usia 3-5 tahun. Anak sudah berani menyatakan dan mengungkapkan ketidaksetujuan dan ketidakmampuan mereka dalam melakukan sesuatu. Pada perkembangan ini anak sudah mampu berbicara secara teratur dan terstruktur dan dapat dipahami orang lain. Mereka sanggup merespon secara negatif atau positif serta menunjukan aturan atau tata bahasa sendiri.

\section{c. Perkembangan Bicara Masa Sekolah}

Perkembangan bicara pada masa sekolah dimulai sejak anak memasuki lembaga pendidikan disekolah dasar. Perkembangan bicara masa sekolah dikategorikan menjadi tiga bidang, yaitu pemakaian bahasa, struktur bahasa dan kesadaran metalinguisti (Suhartono, 2005). Pada perkembangan pragmatik anak mengalami perkembangan bahasa lisan sesuai dengan konteks secara komunikatif dengan memperhatikan lawan bicara, media 
dan situasi saat berbicara. Pada perkembangan ini anak mulai mengerti bicara dengan tepat dan komunikatif, mulai mendeskripsikan sesuatu, mampu menghasilkan cerita secara lisan, dan berani mengemukakan pendapat.Pada perkembangan semantik dan kosa kata terjadi penambahan jumlah kata yang dapat dipahami dan digunakan kata dengan makna yang tepat. Pemahaman makna akan ditegaskan anak dalam bentuk penggunaan bahasa secara lisan. Kemampuan anak membuat definisi dipengaruhi oleh pengelaman anak sebelumnya. Ketika anak mempunyai kesempatan bercakap-cakap, maka anak akan berusaha mengembangkan potensi berbahasa (bicara). Wawasan bentuk kata atau morfologi membantu anak dalam ketepatan mengucapkan kata-kata komplek.

\section{Gangguan Berbicara Anak Usia Dini}

Anak usia 0 hingga 6 tahun merupakan makhluk yang sangat lucu. Orang tua atau orang dewasa seringkali mengikuti cara bicara anak karena dianggap lucu, namun hal ini akan berdampak tidak baik dalam perkembangan bicara anak. Davidoff mengutarakan bahwa bayi harus selalu diajak bicara dan didengar kebutuhannya(Juniati, 1998). Apabila terdapat orang tua atau orang dewasa tidak dilakukan kegiatan tersebut, maka dikemudian hari anak akan mendapatkan kesulitan dalam berkomunikasi dengan orang lain. Orang tua disekitar anak harus selalu mengajak anak berkomunikasi. Hal ini dapat membuat anak merasa senang dan membantu anak untuk mengungkapkan apa yang sebenarnya diinginkan oleh anak.

Anak memperoleh bahasa disekitar mereka secara alamiah. Pada usia 6 hingga 18 bulan, anak sudah dapat berkomunikasi dengan mengeluarkan kata-kata pertamanya. Anak yang mengalami kesulitan memperoleh bahasa untuk berkomunikasi dimasukkan kedalam golongan anak yang mengalami gangguan berbahasa. Perkembangan bahasa anak bergantung pada lingkungan sekitar serta pengalaman yang diperoleh anak selama masa perkembangan dan proses kematangan otak dan kesiapan mereka belajar berbicara. Perkembangan bahasa anak dipengaruhi dan mempengaruhi seluruh aspek perkembangan lain, seperti aspek kognitif dan sosial-emosional anak perkembangan fisik-motorik. 
Gangguan bicara yang diderita anak sering memberikan beban mental pada anak, sehingga berdampak pada psikologisnya. Misal: tidak diterima oleh teman sebaya, dikucilkan saat bermain, dan lain sebagainya. Gangguan bicara pada anak salah satunya adalah keterlambatan berbicara. Keterlambatan berbicara adalah sebuah keadaan pada saat perkembangan bahasa anak berada dibawah umum kronologisnya secara nyata (Suhartono, 2005). Keterlambatan berbicara merupakan salah satu penyebab gangguan perkembangan anak yang sering ditemukan. Gangguan ini memiliki progres dan signifikan dikarenakan berbagai sebab. Pada anak sekolah, angka kasus gangguan bicara dan bahasa berkisar antara 5-10\%. Pada anak normal tanpa gangguan bahasa dan berbicara perlu dilakukan stimulasi kemampuan bicara dan bahasa anak dimulai sejak lahir dengan menstimulasi sejak dalam kandungan. Dengan stimulasi ini diharapkan kemampuan berbicara dan bahasa pada anak menjadi lebih optimal, sehingga dapat meningkatkan kualitas komunikasi anak di lingkungan.

\section{a. Faktor Penyebab Gangguan Berbicara Anak Usia Dini}

Keterlambatan bahasa pada anak usia pra-sekolah semakin meningkat pada masa sekarang ini. Faktor penyebab gangguan berbicara pada anak sangat beragam. Terdapat beberapa resiko yang harus diwaspadai. Semakin awal kita mendeteksi kelainan atau gangguan tersebut akan semakin baik pemulihan pada gangguan tersebut. Semakin cepat mengetahui penyebab gangguan bicara dan bahasa pada anak maka semakin cepat dapat menstimulasi dan mengintervensi anak yang mengalami gangguan berbicara.

Beragam faktor yang menyebabkan gangguan bicara pada anak, yaitu keterbatasan kognitif dan faktor keturunan (Papalia, Diane E; Old, Sally Wendkos \& Feldman, 2008). Anakanak yang mempunyai keterbatasan kognitif membuat anak kesulitan mempelajari struktur bahasa. Sebagian anak yang terlambat berbicara memiliki sejarah otitis media (peradangan dibagian tengah telinga) antara usia 12 sampai 18 bulan dan kemampuan bahasanya meningkat ketika infeksi ini, yang berkaitan dengan kehilangan kemampuan mendengar, sembuh. Faktor keturunan juga memainkan peran dalam keterlambatan bicara pada anak. Hasil penelitian mengungkapkan sekitar 3.039 
pasa anak kembar berusia 2 tahun, apabila salah seorang dari kembaran monozigotik memiliki 5\% dari pengetahuan kosakata maka kembarannya memiliki 80\% kemungkinan untuk memiliki keterlambatan berbicara yang sama. Perkembangan bahasa yang terlambat dapat berakibat terhadap perkembangan kognitif, emosional dan sosial yang lebih luas. Anak yang tidak biasa salah dalam menyebutkan kata (2 tahun), tidak memiliki perbendaharaan kosa kata yang buruk atau kesulitan menamai objek (3 tahun) akan cenderung memiliki ketidakmampuan membaca (5 tahun). Anak yang tidak berbicara atau memahami sebagaimana teman sebayanya, maka anak tersebut cenderung dinilai negatif oleh orang dewasa atau anak lain.

Penyebab anak memiliki gangguan bicara dan bahasa berawal mulai dari proses pendengaran. Proses tersebut diawali dari sambungan rangsangan ke otak, otot atau organ pembuat suara. Ada beberapa penyebab gangguan berbicara seperti misalnya kelainan organ bicara, gangguan pendengaran, kelainan genetik atau kromosom, retardasi mental, autisme, mutism selektif, keterlambatan fungsional, afasia reseptif dan deprivasi lingkungan. Penyebab keterlambatan berbicara dari faktor lingkungan terdiri dari status ekonomi sosial, tehnik pembelajaran yang kurang tepat, sikap orangtua terhadap anak dan kondisi alam lingkungan. Gangguan bicara pada anak dapat disebabkan karena memiliki kelainan organik yang mengganggu sistem tubuh mencakup pendengaran, otak dan fungsi motorik lainnya(Dokter RSMK Cikarang, 2012). Beberapa penelitian menunjukkan penyebab gangguan bicara pada anak adalah adanya gangguan hemisfer dominan yang biasanya merujuk ke fungsi otak kiri. Beberapa anak juga ditemukan penyimpangan bagian korpus kalosum, otak kanan dan lintasan pendengaran yang saling berhubungan(Judarmanto, 2006).

Penyebab dan jenis keterlambatan bicara pada anak dibedakan menjadi dua yaitu keterlambatan bicara ringan dan keterlambatan bicara organik. Keterlambatan bicara ringan sering disebut keterlambatan bicara fungsional. Jenis keterlambatan bicara ini biasanya disebabkan karena gangguan gerakan mulut, ketidakmatangan fungsi organ bicara dan koordinasi oral motor atau. Keterlambatan bicara fungsional ini merupakan penyebab yang sering dialami oleh sebagian anak. 
Keterlambatan bicara golongan ini biasanya ringan dan hanya merupakan ketidakmatangan fungsi bicara pada anak namun pada usia tertentu (terutama setelah usia 2 tahun) cenderung akan membaik.

Keterlambatan bicara lain yaitu keterlambatan organik atau non-fungsional. Gejala umum keterlambatan bicara nonfungsional ini adalah adanya gangguan kemampuan pemecahan masalah visuo-motor dan gangguan bahasa reseptif. Keterlambatan bicara jenis disebabkan karena adanya gangguan pada organ tubuh terutama adanya kelainan di bagian otak. Keterlambatan bicara non-fungsional ini disertai dengan gangguan pendengaran, gangguan kecerdasan, autisme dan kelainan neurologis bawaan.

Ciri kelainan neurologis bawaan seperti gangguan anatomis telinga, gangguan mata, cerebral palsy, wajah dismorfik, perawakan pendek, mikrosefali, makrosefali, tumor otak, kelumpuhan umum, infeksi otak, dan gangguan neurologis lainnya. Sedangkan gangguan pendengaran pada anak yaitu mereka tidak dapat mengikuti perintah dan tidak memahami apa yang ingin dikatakan. Gangguan kecerdasan pada dapat dilihat apabila anak tidak dapat melakukan gerakan dada, menjabat tangan, menanggapi respon non-verbal dan tidak dapat mengikuti perintah ringan. Gejala autisme pada anak dapat dideteksi apabila tidak ada kontak mata atau pandangan mata pada saat melakukan komunikasi dengan anak.

\section{b. Ciri-Ciri Gangguan Berbicara Anak Usia Dini}

Keterlambatan bicara pada anak muncul apabila mengalami beberapa gejala sebagai berikut : (1) anak yang berusia sepuluh bulan belum dapat mengucapkan bunyi fonim berbentuk suku kata (melister); (2) anak belum menguasai beberapa kata yang berarti selain "mama dan papa" atau belum dapat menunjukan apa yang diinginkan pada usia delapan belas bulan; dan (3) anak belum dapat mengucapkan rangkaian kalimat yang terdiri dari atas dua kata atau bicaranya tidak dapat dimengerti atau dipahami oleh orang tuanya dan anak tidak mengerti tentang apa yang dikatakan kepadanya pada usia dua tahun. Anak yang mengalami keterlambatan bicara mempunyai ciri-ciri, sebagai berikut : (Judarmanto, 2006) 


\begin{tabular}{|c|c|}
\hline Usia & Deskripsi \\
\hline $4-6$ bulan & $\begin{array}{l}\text { Tidak dapat menirukan suara yang dikeluarkan } \\
\text { orang tuanya. } \\
>\text { belum dapat tertawa atau berceloteh. }\end{array}$ \\
\hline $8-10$ bulan & $\begin{aligned}> & \text { tidak dapat mengeluarkan suara yang menarik } \\
& \text { perhatian. } \\
> & \text { belum dapat bereaksi ketika dipanggil namanya. } \\
> & \text { tidak dapat memperlihatkan emosi seperti } \\
& \text { menangis dan tertawa. }\end{aligned}$ \\
\hline 12 - 15 bulan & $\begin{aligned}> & \text { belum dapat menunjukkan mimik. } \\
> & \text { belum mampu mengeluarkan suara dari mulut. } \\
> & \text { Tidak dapat menunjukkan usaha berkomunikasi } \\
& \text { apabila membutuhkan sesuatu. } \\
> & \text { belum mampu memahami arti "tidak boleh" } \\
& \text { atau "daah daaah" } \\
> & \text { tidak dapat memperlihatkan } 6 \text { mimik yang } \\
& \text { berbeda. } \\
> & \text { belum dapat mengucapkan 1-3 kosa kata. }\end{aligned}$ \\
\hline 18 - 24 bulan & $\begin{aligned}> & \text { belum dapat mengucapkan } 6 \text {-10 kosa kata } \\
> & \text { tidak menunjukkan ekspresi sesuatu yang } \\
& \text { menarik perhatian mereka. } \\
> & \text { belum dapat mengikuti perintah sederhana. } \\
> & \text { belum dapat merangkai } 2 \text { kata menjadi kalimat. } \\
> & \text { tidak memahami fungsi alat rumah tangga } \\
& \text { seperti sapu, sikat gigi dan telepon. }\end{aligned}$ \\
\hline
\end{tabular}


belum dapat menirukan tingkah laku atau katakata orang lain.

$>$ apabila ditanya tidak mampu meunjukkan anggota tubuhnya.

30 - 36 bulan $>$ tidak dapat dipahami oleh anggota keluarga.

$>$ tidak menggunakan kalimat sederhana saat bertanya dan tidak dapat dipahami oleh orang lain selain anggota keluarga.

3-4 tahun $>$ tidak mengerti perintah verbal, tidak mengucapkan kalimat dan tidak memiliki minat bermain dengan sesamanya tidak dapat menyelesaikan kata.

Anak mengalami keterlambatan berbicara dan berbahasa sebagian besar juga mengalami retardasi, distribused atau mengalami gangguan pendengaran pada tahap awal perkembangan. Penelitian menunjukkan bahwa anak-anak yang dilangit-langit mulutnya terbelah cenderung underachieveving dan menunjukkan masalah dalam kepribadiannya seperti malu, menarik diri, tetapi tidak ada bukti yang cukup bahwa mereka secara psikologis atau emosional mengalami hambatan.Beberapa anak yang menderita stutterers sering menunjukkan kecemasan yang tinggi dan kecenderungan mempunyai opini yang rendah tentang diri sendiri.

\section{c. Cara Menangani Gangguan Berbicara Anak Usia Dini}

Melakukan deteksi dini gangguan bicara dan bahasa pada anak harus dapat dilakukan oleh semua individu yang terlibat dalam penanganan anak. Orang tua, keluarga, dokter kandungan yang merawat sejak kehamilan, tetangga dan dokter anak yang merawat anak tersebut harus terlibat pada deteksi dini tersebut. Penanganan keterlambatan bicara pada anak harus dilakukan melalui pendekatan medis sesuai dengan penyebab kelainan tersebut dan metode lainnya. Biasanya, hal 


\section{Asrul Faruq, Dhiarti Tejaningrum

ini memerlukan penanganan berbagai pihak dan mencakup multi disiplin ilmu di bidang kesehatan. Dokter anak menjadi faktor penting agar anak tumbuh dan berkembang sesuai dengan tahapan normal yang mencakup tumbuh kembang anak, neurologi anak, alergi anak, rehabilitasi medik, dan klinisi atau praktisi lainnya yang berkaitan.

\section{METODE PENELITIAN}

\section{Tempat Pengamatan}

Kegiatan pengamatan dilakukan di kelas Play group kelompok B, Safa Preschool Yogyakarta. Pemilihan sekolah Safa Preschool sebagai lokasi penelitian meliputi beberapa pertimbangan, antara lain di sekolah Safa Preschool memberikan layanan pendidikan pada anak usia 2-6 tahun, melayani anak-anak yang mempunyai kebutuhan, memberikan pengalaman kepada anak usia dini agar mendapatkan dunianya, serta memberikan pelayanan pada anak agar anak mampu tumbuh dan berkembang secara optimal. Observer memusatkan diri pada proses pembelajaran di kelas play group kelompok B.

\section{Subjek Pengamatan}

Subjek pengamatan merupakan seluruh orang yang terlibat pada proses pembelajaran di kelas play group kelompok B. Subjek pengamatan meliputi kegiatan pembelajran, guru kelas (educator), guru pendamping (asisten) dan anak di kelas play group kelompok B Safa Preschool .

\section{Teknik Pengamatan}

Teknik pengamatan yang digunakan adalah wawancara dan observasi langsung. Teknik pengamatan ini dilakukan secara alami dan natural pada sumber data awal untuk mengumpulkan data di lapangan. Wawancara ditujukan kepada sumber data yang terlibat dalam pembelajaran di kelas play group kelompok B atau kelas lanjut maupun orang-orang yang mengetahui lebih dalam anak yang mengalami keterlambatan berbicara. Sumber data dalam teknik wawancara adalah kepala sekolah, guru kelas, asisten sekolah Safa Preschool dan orang tua. Metode observasi langsung bertujuan untuk mengetahui proses pembelajaran dan gangguan perkembangan bahasa pada anak di kelas play group kelompok B. Kegiatan obsevasi langsung dilakukan oleh peneliti di dalam maupun di luar kelas 
dengan mengamati seluruh kegiatan guru dan anak pada proses pembelajaran. Observer menggunakan catatan lapangan untuk mendokumentasikan dan mencatat hasil pengamatan.

\section{HASIL DAN PEMBAHASAN}

\section{A. Deskripsi Stimulasi Keterlambatan Berbicara Anak}

Pengamatan yang dilakukan penulis selama satu minggu di kelompok bermain Safa Preschool Yogyakarta, khusunya dalam perkembangan bahasa anak baik kemampuan bicara, mendengar, menulis dan membaca terdapat seorang anak usia 3-4 tahun yang mengalami kesulitan bicara. Anak mengalami kesulitan dalam mengungkapkan gagasan atau pendapat. Penguasaan kosa kata anak sangat kurang, hal ini ditinjau dari kemampuan perkembangan pada usianya, sehingga anak mengalami gangguan sosial-emosional dalam berinteraksi dengan teman-temannya. serta kosakata. Anak sering bermain sendiri dan terlihat emosi saat meminta sesuatu. Anak cenderung dijauhi oleh teman saat bermain. Safa Preschool melakukan beberapa hal dalam menstimulasi kemampuan bicara anak.

\section{Observasi Kebutuhan Anak}

Kegiatan pembelajaran bagi anak yang mengalami keterlambatan bicara dimulai dengan melakukan observasi kebutuhan anak selama 3 bulan. Kegiatan observasi dilakukan dengan menganalisis seluruh perkembangan anak. Observasi dilakukan oleh guru dan kepala sekolah selama kegiatan pembelajaran dan kegiatan yang ada disekolah. Selain melalui observasi, untuk mengetahui kebutuhan anak maka pihak sekolah melakukan wawancara kepada orang tua. Pihak sekolah juga menyarakan melakukan tes psikologi untuk mengetahui kebutuhan anak. Hasil observasi dan wawancara digunakan sebagai dasar kegiatan pembelajaran yang dapat disimpulkan bahwa anak mengalami gejala awal keterlambatan bicara, dengan ciri-ciri sebagai berikut:

a. Pada usia dua tahun, anak belum mampu mengucapkan rangkaian kalimat yang terdiri dari dua kata atau lebih dan bicaranya tidak dapat dipahami oleh orang tua dan anak tidak mengerti tentang apa yang dikatakan kepadanya. 
b. Anak tidak dapat mengucapkan kalimat, tidak mengerti perintah verbal dasar dan tidak memiliki minat bermain dengan teman sebaya.

c. Anak cenderung gagap, tidak dapat dipahami orang lain.

d. Anak mengungkapkan perasaan dengan teriakan dan gerakan menunjuk.

e. Anak berbicara dengan suara keras dan nada volume yang tinggi.

\section{Perencanaan Pembelajaran}

Proses pembelajaran pada anak yang mengalami keterlambatan bicara diawali dengan membuat perencanaan pembelajaran yang harus disesuaikan dengan kemampuan dan kebutuhan anak. Guru menyiapkan alat dan bahan, menentukan kegiatan, merancang RKH (Rencana Kegiatan Harian) sesuai indikator keberhasilan sehingga proses pembelajaran dapat fleksibel serta dapat memenuhi seluruh kebutuhan anak. Guru dapat memberikan kesempatan pada anak untuk bereksplorasi agar menstimulasi perkembangan anak dan memenuhi kebutuhan anak.

Rencana program pembelajaran digunakan agar pembelajaran lebih efektif dan fleksibel sehingga lebih memudahkan guru untuk memenuhi kebutuhan anak pada proses pembelajaran. Rencana kegiatan pembelajaran disusun secara detail dalam rencana program harian dan mingguan. Pada rencana program ada bagian tabel yang menerangkan kegiatan hariannya. Perencanaan program disusun oleh guru pada setiap minggu sebelum pembelajaran dimulai. Guru mencermati dan mengimplementasikan indikator dan tujuan yang harus dicapai oleh anak dari kurikulum yang telah disusun. Seluruh indikator yang disusun harus sesuai dengan kurikulum sehingga didalam satu program tersebut ada semua aspek yang meliputi aspek kognitif, fisik motorik, sosial emosional dan bahasa,. 


\section{Pelaksanaan Pembelajaran}

Pelaksanaan pembelajaran dilaksanakan secara fleksibel sesuai dengan kebutuhan anak. Perencanaan program yang sudah disiapkan oleh guru hanya menjadi acuan dalam menstimulasi dan penilaian perkembangan anak. Pada pelaksanakan pembelajaran terdiri dari empat (4) tahap kegiatan, yaitu kegiatan pembukaan, kegiatan inti, istirahat dan penutup. Setiap tahap kegiatan pembelajaran, guru selalu memberikan kesempatan pada anak yang mengalami keterlambatan bicara untuk mengungkapkan pendapat maupun cerita. Guru dan anak-anak lain membantu anak yang mengalami keterlambatan bicara dengan mengucapkan kosakata dengan pelan.

Tahap kegaiatan pembukaan, guru mengajak anak untuk menyanyi, bermain, berdo'a dan bercerita. Guru juga memberikan kesempatan pada anak untuk memimpin do'a serta bercerita didepan kelas. Pada tahap kegiatan inti, guru dan anak bermain peran. Pelaksanaan pembelajaran melalui kegiatan main peran laksanakan bersama. Guru menstimulasi kegiatan anak dengan memasangkan anak yang mengalami keterlambatan bicara dengan anak yang perkembangan bicara sudah lancar. Kegiatan bermain peran dilakukan anak secara individu. Anak harus mengeksplorasi alat dan bahan yang digunakan untuk bermain peran. Guru mendampingi anak dengan menanyakan kegiatan yang sedang anak lakukan dan apa saja benda yang berada disekitar anak. Guru mengulang mengucapkan kata yang disebutkan oleh anak secara pelan dan meminta anak untuk mengulang-ulang kata yang diminati oleh anak.

Guru harus membantu anak untuk bermain peran bersama teman dengan membantu anak mengucapkan katakata yang ingin dikatakan anak. Guru memberikan kesempatan pada anak untuk bercerita mengenai hal yang diminati oleh anak. Guru mengajak anak bercerita tentang setiap kegiatan. Guru selalu mengulang kata yang diucapkan anak dengan pelan dan anak diminta untuk mengulang kata tersebut. Pada tahap kegiatan istirahat, guru mengajak anak bermain bersama, membaca buku bersama dan bercerita. 


\section{Asrul Faruq, Dhiarti Tejaningrum 174}

Guru mengajarkan kosakata pada anak melalui kegiatan rutin setiap hari dan dari barang-barang disekitar anak.

Pada tahap kegiatan penutup, guru mengajak anak untuk membereskan seluruh mainan dan melakukan diskusi bersama. Guru mengajak anak untuk bercerita mengenai rutinitas apa saja yang anak lakukan selama satu hari dengan tujuan mengajak anak mengungkapkan pikiran mereka. Guru memberikan kesempatan pada semua anak. Guru menghargai cerita anak dan guru menyimpulkan setiap cerita anak. Guru memberikan kesempatan yang sama pada anak untuk melakukan tanya jawab.

\section{Evaluasi Pembelajaran}

Penyiapan penilaian harus diberikan guru sebelum kegiatan pembelajaran. Penilaian yang disiapkan guru berupa indikator pembelajaran dan buku catatan perkembangan anak. Hal tersebut bertujuan untuk memudahkan guru mengamati dan mengobservasi anak tentang pencapaian tahap perkembangan guru, sehingga guru dapat melihat proses dan hasil pembelajaran. Guru melakukan penilaian terhadap perkembangan anak dengan mencatat setiap tahapan perkembangan yang dicapai oleh anak dan mengamati proses pembelajaran atau kegiatan yang dilakukan anak dan.

Penilaian guru dapat berupa portofolio yang berisi tahapan yang telah dicapai oleh anak sehingga guru mengetahui proses pencapaian perkembangan anak. Guru mencatat kosakata baru yang diucapkan anak dan kosakata yang sudah jelas diucapkan anak. Dari buku catatan perkembangan, guru dapat mengatahui perkembangan bicara anak dan harus dilaporkan kepada orang tua setiap 3 bulan sekali dalam bentuk raport atau hasil penilaian anak. 


\section{KESIMPULAN}

Gangguan perkembangan berbicara pada anak usia dini dapat ditangani dengan baik sedini mungkin. Keterlambatan bicara pada anak dapat mempengaruhi aspek perkembangan sosial emosional anak. Anak yang mengalami keterlambatan bicara pasti mengalami gangguan berinteraksi dengan orang disekitar anak dan mereka cenderung diabaikan teman-temannya. Selain itu, perkembangan emosional mereka terganggu jika keinginannya tidak dipenuhi karena orang lain tidak mengerti apa yang anak berusaha ungkapkan. Keterlambatan bicara pada anak dapat disebabkan beberapa faktor, seperti gangguan pendengaran, pola asuh, lingkungan dan genetika.

Oleh sebab itu, penulis memberikan beberapa saran, antara lain: (1) teterlambatan bicara harus dideteksi sedini mungkin; (2) orang tua dan guru harus mengatahui tahap perkembangan pada setiap aspek-aspek perkembangan anak; dan (3) orang tua dan guru memberikan kesempatan yang luas kepada anak untuk mengungkapkan pikiran dan pendapat mereka. 


\section{DAFTAR PUSTAKA}

Ahmadi, Abu \& Sholeh, M. (2005). Psikologi Perkembangan. Jakarta: Rineka Cipta.

Dokter RSMK Cikarang. (2012). Anak Terlambat Bicara.

Hamalik, O. (2004). Proses Belajar Mengajar. Jakarta: Bumi Aksara.

Hurlock, E. B. (1999). Psikologi Perkembangan: Suatu Pendekatan

Sepanjang rentang Hidup. Jakarta: Erlangga.

Judarmanto, W. (2006). Keterlambatan Berbicara Berbahaya Atau

Tidak. Retrieved from http://artikel-sd/Keterlambatan berbicara-

Speech delayed.htm

Juniati, M. (1998). Psikologi suatu Pengantar: terjemahan introducton to Psychology. Jakarta: Erlangga.

Kushartanti, D. (2005). Pesona Bahasa: langkah awal memahami linguistik. Jakarta: Gramedia.

Mar'at, S. (n.d.). Psikologi Perkembangan. Bandung: PT Remaja Rosdakarya.

Masito. (2005). Pendekatan Belajar Aktif di Taman Kanak-Kanak. Jakarta: Depdiknas.

Papalia, Diane E; Old, Sally Wendkos \& Feldman, R. D. (2008). Human Development. Jakarta: Kencana Prenada Media Group.

Patmodewo, S. (2003). Pendidikan Anak Pra Sekolah. Jakarta: Rineka Cipta.

Santrock, J. W. (2007). Perkembangan Anak. Jakarta: Erlangga.

Soetjiningsih. (1995). Tumbuh Kembang Anak. Jakarta: EGC.

Suhartono. (2005). Pengembangan Keterampilan Berbicara Anak Usia

Dini. Jakarta: Depdiknas.

Tarigan, H. G. (1985). Psikolinguistik. Bandung: Angkasa.

Zamzami, H. dan. (n.d.). Peningkatan Keterampilan Berbahasa Indonesia. Jakarta: Depdikbud. 